\title{
IOWA'S "LITTLE SWITZERLAND"
}

By JAMES D. Allen

The attractive area in the Hawkeye state comprising its northeast corner and located in general way east of Decorah, West Union and Oelwein, and north from Manchester, Dyersville and Dubuque, long has been characterized the "Little Switzerland of Iowa." This is because of the generally rugged character of the land surface, occasioning the establishment of roads in disregard of section lines, the scenic qualities of the landscape, with hills and valleys, creeks and rivers, and the sweeping curves of the great Mississippi.

Until paved highways were constructed and use of the automobile more universal, this beautiful portion of Iowa was somewhat inaccessible and not so well appreciated as in later years, when it has been visited with great regularity and valued for its vacational advantages. Here is to be found scenery and recreational possibilities not excelled elsewhere in all America.

No bridges spanned the great border river between Dubuque and LaCrosse, until in the thirties ambitious individuals sought to connect Iowa and Wisconsin communities by promoting the erection of a mammouth steel toll structure from Lansing, on the Iowa side, to Wisconsin highway No. 35, which connected LaCrosse and Prairie du Chien, the latter the site of old Fort Crawford of early pioneer days, the closest villages to the bridge on that side of the Mississippi being DeSoto and Ferryville.

Soon paved Iowa highway No. 9 was extended north and east from Waukon to Lansing, and the county seat town also connected by a paved highway with Postville on highway No. 18 to the south. These public improvements soon opened this great trade section of the state to Waterloo and LaCrosse wholesale establishments, enabling them to reach the retail trade by daily truck deliveries. 
Subsequently, in a couple of years, another such toll bridge was built across the river between Prairie du Chien and Marquette, making Iowa highway No. 18 the paved route to Madison and Milwaukee. The traffic over these bridges brought new life and opportunity to this section of Iowa, as well as to the southwest areas of Wisconsin. But neither enterprise became self-supporting upon the volume of toll traffic afforded, and encountered financial difficulties because of the heavy indebtedness assumed in their original construction costs which were secured by mortgages upon these properties.

Stockholders became restive, and at Prairie du Chien the holder of the mortgage took over the enterprise. But at Lansing contesting groups of stockholders unfortunately seeking stock control, resulted in a receivership and subsequent court proceedings which eventually largely absorbed the toll income and saddled upon the corporation burdensome attorney's fees. Finally, when a connecting causeway and wooden bridge over the Burlington railway and what is called the Winneshiek channel, between a river island and the Wisconsin shore line, was carried out by high water and ice several winters ago, no funds were available for reconstruction, and this bridge has since been closed and not operated. The great Blackhawk bridge stands high above the river, weather-beaten, silent, grim and useless-a monument to the folly of those who sought to control rather than to operate successfully. Thus the area has been deprived of the convenient facilities of a connecting thoroughfare between Iowa and Wisconsin at that point.

\section{BEAUty of SECtion LONg APPREciated}

The attractiveness of this section of Iowa has been known and appreciated for many years. Lansing and McGregor were early river town gateways to inland points in Iowa, and a large volume of river shipping of 
commodities both in and out of the state enjoyed for many years. Luxemburg, Guttenburg, Elkader and Garnavillo are quaint towns nestled in the hills of this section, and with the places previously mentioned, largely supply the local trading and community interests.

In the heralded events of a rushing age this spot had all but been overlooked. With its old trails, log cabins and many reminiscences of the frontier days and the Indians, there is delight for the artist, the geologist, the botanist, the historian and the pictorial photographer, in fact for everyone who loves nature's wild beauty.

Old Lansing, with its pearl button factory, state hatchery, fisheries, and other industries, still remains ancient and fanciful, but is a good trading point. Nestling in the high and picturesque hills that skirt the Mississippi with leaping streams and rivlets, it is the fisherman's paradise with abundance of pike, bass, sheepshead, bluegills, crappies and trout. Mount "Hosmer" rears its shaggy outlines over the town, with an improved city park on its top; the majestic lover's leap, from whose imminence, the legend tells, the beautiful Indian Princess Eulitto leaped to her death in the Mississippi river; the old "Capoli," with its neighbors-the "Kalatania" and "Naikantania" on the main channel, a little south of the village, and "Gabbitt's Point" to the north, whose bald castle-formed tops are frequently hidden in the clouds-lures that none can resist if they but knew of the charms of this section.

On one of the Mississippi river's highest bluffs, three miles north of McGregor, lies the 1,000-acre Effigy Mounds National Monument, donated by the state a year ago to the national parks service and opened for tourists June 15 of this year. A scenic expanse spreads between two of the ancient mounds. Trails up steep bluffs are being constructed in the locality where 100 Indian mounds are located. This is one of the outstanding scenic and historical spots in that section of the state. At one point is a huge bear mound and nineteen conical mounds. 
This new park lies partly in two counties, Allamakee and Clayton. In addition 204 acres are still owned by the state of Iowa, which also will be turned over to the government. It is believed that the mound builders were in Iowa from 900 to $1500 \mathrm{~A}$. D., but little is known of them excepting through Indian legend and the mounds they left. Only limited explorations have been made by vandals uncovering burial pottery, but scientific examinations will be made under qualified educational authorities.

\section{Caves ANd Hills ABound}

Long ago the local vacationer, the Iowa tourist and the out-of-state visitor knew of the caves large and small within the range of this section. Two especially, among the larger, are Crystal lake cave, at Dubuque, and Wonder cave fifteen miles north of Decorah. A little way into Minnesota, not too far from the Iowa line, are Niagra cave, and Mystery cave, immense and unusual in attractiveness. Most of these caves are open to visitors and operated by private interests. Lighted with electricity, one may explore their deep corridors and view the glistening walls, where sparkling stalactites from the ceiling reach down and point toward the stalagmites rising from the floors. Beauty and color abound. In Wonder cave near Decorah is found a stalactite measuring seventy-five feet from its base to its tip, beautiful in formation and among the giants of the world.

At McGregor the scientists and the educators make summer habitat with its wild life school and educational lectures in season; here scenic beauty also abounds, the surrounding hills making the town look like a Swiss village in the Alps; "Pike's Peak," the "Heights," the caves in the hills, where several generations of venturesome lads have explored and dug to their heart's content; also the old Scenic hotel that was important as a stopping place when the ferry over the Mississippi 
river was operated prior to the building of the Marquette bridge, and the ebb and flow of the river traffic.

Everywhere in the north and east tip of this area in the gullies between the hills and abrupt precipices, both in Iowa and Wisconsin, may be found and had for the asking, beautiful many-colored, honey-combed volcanic stones-resembling old Venetian lace-so popular and attractive in rock gardens and other flowery retreats.

In the near vicinity of this interesting section, as it is approached, other quaint attractions always enhance the enjoyment of the journey. There is Saint Anthony's chapel, the smallest church in the world, at Festina; and one may stop at Spillville, near Calmar, and see the great collection of wonderful cathedral clocks. They are the handicraft of the famous Bily brothers, plain farm men, who after the day's farm work was done, spent their evenings over a period of more than twentyfive years, creating these masterpieces. These handcarved wooden clocks draw thousands to the village, just as they formerly did when they occupied a building on the farm four miles north from town, attendance figures showing 45,000 persons last year traveled the dirt and gravel roads that branch into this hamlet.

The Bily clocks are now housed in a two-story brickfront building which has a history all its own, as this building was once the domicile of the inspired Antonin Dvorak, the great composer, during his stay in Spillville the summer of 1893, when he composed "Humoresque" on the bank of pretty little Turkey river. A memorial clock to Dvorak is housed in an upstairs room, where the composer of "New World Symphony" played the organ, most of the scores of this Fifth Symphony being written there. How many Americans know that the gladest, the sadest-the liltingest tune that has charmed the world was composed on the banks of the little stream in northeastern Iowa? "Humoresque" has brought laughter and tears the universe over. It has been the favorite with millions of people-every music 
lover knows it. Is there anyone who has not been enraptured and enthralled by this beautiful composition? Name a musician who has never played it. But did you know that this melody which has played upon the heartstrings of the world, gained inspiration for its composing at quiet Spillville?

\section{Old Milititary 'Trail}

The military glamour of the section was largely monopolized one hundred years ago by Prairie du Chien, then known as Fort Crawford, and to the west in Iowa by Fort Atkinson connected with the Mississippi river just north of McGregor by the Old Military Trail, built in 1840 by United States troops, and used until about 1848, when the Indians were removed to Minnesota from the vicinity of Fort Atkinson and it was discontinued. The road from the river was up a ravine, traversing the tract recently created as a national monument. At Monona the trail merges with Highway 18.

A granite boulder set by the Daughters of the American Revolution, in connection with the Iowa Historical Department at Des Moines, two decades ago, marked the location. It bears a bronze tablet on its face containing the following legend:

"Old Military Trail. This rock marks the beginning of the Old Military Trail first used in the summer of 1840 by troops from Fort Crawford in Wisconsin when building Fort Atkinson in Iowa. It served as a highway for the movement of troops and supplies between Fort Crawford and Fort Atkinson."

Incidents of the opening of this trail are told by Florence L. Clark, as it is now planned to restore it by clearing out the vines, brush and timber growth, and opening a footpath through the new government park. The story goes that the war department planned to open a road west from McGregor's landing almost opposite Prairie du Chein. Alexander McGregor had in 1833 acquired 160 acres at the Iowa landing, with $\$ 300$ he 
had obtained by selling land which is now in the loop at Chicago. He was in 1840 operating a ferry to his projected Iowa town site.

\section{Fur Trader Wins OUt}

Hercules Dousman, partner at Prairie du Chien of John Jacob Astor in the fur trade, and a rival of McGregor's in the ferry business, opposed the war department choice of McGregor's landing as the beginning of the military trail. Dousman opened up his own trail first, four miles north of the landing that is now the site of McGregor.

The legend is that gifts of whiskey to soldiers and carriage rides to officers by Dousman had a great deal to do with the official placing of the trail where the fur trader wanted it. Dousman himself became a familiar figure on the trail, particularly in winter when he often sped over the river ice road in an ornate sleigh driving a team of white horses on his way to trade with the Indians. In summer, ferries landed at the foot of the trail where a large stable was built. Six and eight horse hitches were used for hauling the wagon loads of military supplies up the steep trail, bound for Fort Atkinson.

For another 10 years following the evacuation of Fort Atkinson immigrants made use of the trail in getting up the Iowa bluffs on their way to take up land in northeastern Iowa and southeastern Minnesota. They called it Smith's landing. The trail had a brief renewal of use in prohibition times when bootleggers used it to get to their stills.

With the establishment of the bridge facilities came a renewed interest in this entire section of Iowa and it rapidly obtained favor as the summer Mecca for those who receive inspiration and relaxation in vacation tours. While Iowa is famed as a prairie state and its farm lands bring rich returns in cultivation, this more picturesque section affords a real joy to those who know and appreciate its attractions, as well as its historic note. 
Copyright of Annals of Iowa is the property of State of Iowa, by \& through the State Historical Society of Iowa and its content may not be copied or emailed to multiple sites or posted to a listserv without the copyright holder's express written permission. However, users may print, download, or email articles for individual use. 